\title{
Food Intake And Visceral Fat Deposition Are Risk Factors Of Incidence And Severity Of Non-Alcoholic Fatty Liver Disease
}

\author{
Risky Ika Riani ${ }^{1}$, Hery Djagat Purnomo², Fatimah Muis ${ }^{1}$ \\ ${ }^{1}$ Division of Nutrition, Faculty of Medicine Diponegoro University -Dr. Kariadi Semarang Hospital, Semarang, \\ Indonesia \\ ${ }^{2}$ Division of Gastroentero-Hepatology, Department of Internal Medicine, Faculty of Medicine Diponegoro \\ University -Dr. Kariadi Semarang Hospital, Semarang, Indonesia
}

Article info

History :

Received : 29 Nov 2017

Accepted : 22 Dec 2017

Available : 31 Dec 2017

\begin{abstract}
Background: Non alcoholic fatty liver disease (NAFLD) is abnormalities of metabolism resulting in fat deposition in the hepatocyte occurred in people who do not consume alcohol. Carbohydrate and fat intake, also visceral fat deposition has been studied as a risk factor of NAFLD, however the results remain elusive.

Objective: To identity the nutritional and clinical risk factors of the incidence and severity of NAFLD.

Methods: This study was done from June to December 2014 in the Dr. Kariadi Hospital Semarang. A case-control group was established comprising 33 patients with NAFLD based on the ultrasonography (USG) criteria (case group) and 34 healthy subject (control group). Carbohydrate and fat intake was assessed by using the food frequency questionnaire (FFQ), visceral fat deposition was measured by body impedance analysis (BIA), and clinical markers were obtained from laboratory data.

Results: Carbohydrate intake, fat intake, and visceral fat deposition were risk factors of the incidence and severity of NAFLD (OR=7.8,C195\% 2.43-25.45; $O R=5.9, C 195 \%$ 2.0-17.57; $O R=50.7, C 195 \%$ 6.16-418.09) and $(O R=0.9, C 195 \%$ $1.06-90.58 ; \quad O R=14.6, \quad C 195 \% \quad 1.37-156.88 ; \quad O R=6.6, \quad C 195 \% \quad 1.17-37.78)$. Multivariate regression showed that the most important risk factor of NAFLD for the incidence and severity were hypertriglyceridemia $(O R=8.7, C 195 \% 2.20-34.44)$ and fat intake $(O R=48.4, C 195 \%$ 2.78-844.1), respectively.

Conclusion: High carbohydrate intake, fat intake, and high visceral fat deposition are risk factors of the incidence and severity of NAFLD. Hypertrig lyceridemia and fat intake are the most important risk factor of NAFLD incidence and severity, respectively.
\end{abstract}

Keywords: Non alcoholic fatty liver disease, carbohydrate intake, fat intake, visceral fat, risk factor

\section{INTRODUCTION}

Non Alcoholic Fatty Liver Disease (NAFLD) is a liver disorder that is histologically similar to Alcoholic Fatty Liver Disease (ALD), but occurs in patients who do not consume alcohol.

*Corresponding Author:

herydjagat@yahoo.co.id 0248446757
This disease is caused by abnormalities of metabolism resulting in fat deposition in the hepatocyte. $^{1,2}$ NAFLD spectrum is very broad, ranging from simple fatty liver, fatty liver disease with NAFLD, Liver Cirrhosis and Hepatocellular Carcinoma. ${ }^{3}$ Approximately $37 \%$ of ALD patients on the simple fatty liver spectrum will develop into Fatty Liver Disease with NAFLD, $45 \%$ develop into cirrhosis within 7 years, and then 5-8\% develop into hepatocellular carcino ma within 1 year. $^{4}$ 
In the last decade, the prevalence of NAFLD around the world has increased rapidly. World Gastroenterology Organization mentioned that NAFLD is the number one liver disease in western countries. An estimated 6 million Americans experience NAFLD. NAFLD incidence in some countries in Asia is reported to be about 5-40\% depending on the population studied. NAFLD prevalence in the general population in Japan in 1988 was about $9-14 \%$ and there has been a significant increase in obese populations in the last two decades. NAFLD in India is estimated at 5-28\%, and in China with liver ultrasound (ultrasound) examination, NAFLD prevalence is approximately $15 \% .^{5}$

Specific research on NAFLD has not been done in Indonesia. Several studies of NAFLD suggested that $30.6 \%$ NAFLD prevalence and important risk factors reported were metabolic syndrome, obesity, type 2 diabetes mellitus, insulin resistance (IR), and hypertriglyceridemia where caused by high food intake of carbohydrate and high fat intake is closely related to these risk factors. 6,7

The objective of this study was to identity the nutritional and clinical risk factors of the incidence and severity of NAFLD.

\section{MATERIALS AND METHODS}

This study was a case-control study. $\stackrel{47}{ }$ The scope of this research was in the field of Clinical Nutrition Sciences and Internal Medicine Sub Section Gastroenterohepatology that conducted in Internal medicine clinic sub Gastroenterohepatology Dr. Kariadi Semarang Hospital between June and December 2014.

\section{Study Subjects}

The target population were patients in the Gastroenterohepatology clinic of Dr. Kariadi Hospital Semarang, with the reasonably affordable population for the case was patients who had been diagnosed with NAFLD, who had been screened early on and there was no change of diet and physical activity in the last 5 years. An population for control was a person who on an ultrasound examination that performed by a Gastroenterohepatology consultant, was not found NAFLD or other liver disease, and there was no history of taking medications that cause liver dis orders.

Inclusion criteria of case subject were patients with: (a)Viewed from NAFLD diagnosed medical record, (b) Positive abdominal ultrasound for NAFLD (c) Not taking any medicines or herbs that interfere with the liver function or that cause fatty liver and (d) Not taking any medicines or herbs that inhibit fat absorption, fat burners, and weight loss (e) Not suffering from liver disease other than NAFLD (f) Passes screening on diet and living habits (see appendix) (g) Willing to be subject of the study. Exclusion criteria were having abnormalities and/or congenital defects that can interfere with research measurements. Inclusion criteria of control subject were patients (a) without history and symptoms of liver disease (b) who had not any liver abnormalities on ultrasound examination. Exclusion criteria in the control group were the same as the case group.

\section{Data processing}

Data collection is done manually using the research form provided. Food intake assessment was done with semiquantitative FFQ, which then conducted data entry using intake analysis program with Nutrisurvey Program. Physical Activity Assessment based on interviews using International Physical Activity Questionnaire (IPAQ) was then calculated with an automatic calculator IPAQ score instrument.

\section{Data analysis}

Univariate analysis of variables analyzed data normality then data is presented in the form of distribution table and description. Bivariate analysis is an analysis to determine the relationship of each risk factor with NAFLD using test in accordance with the variables analyzed. Data from the variables corresponding to the $\mathrm{p}$ value $<0.25$ were included in a mu ltivariate $\log$ istic regression analysis.

The study was approved by the UniversityHospital's Ethics Committee (no. 128/EC/FKRSDK/2014) and all patients provided written informed concept before participation.

\section{RES ULTS}

\section{Overview of Research Subject}

NAFLD group obtained 33 subjects in which 15 men and 18 women, while healthy controls were 34 subjects with 12 males and 22 females. There were no difference of characteristics of subjects in this study in general. The age range was 28-68 years and the mean age was 43.39 years. While the control group obtained 34 subjects, with female gender more than men. Age range 28-55 years and average age 40.76 years. The mean of Waist circumference in the NAFLD group was higher than the control. Based on Waist circumference and sex by Asian classification, NAFLD subjects had more central obesity than those who did not, while control subjects who had fewer central obesity than those who did not. The mean of BMI in the NAFLD group was higher than the control, there was even a NAFLD subject with $43 \mathrm{~kg}$ / m2 IMT (Table 1).

Most of the subjects from both groups are civil servants and all research subjects in both groups have middle to upper economic level where their income is above minimum wages rate for Semarang in 2014. Subjects in both groups have more activity than those with low activity. None of the subjects of the two groups had high activity. The NAFLD group in this study had a diverse NAFLD Fibrosis Score, but after classification according to its degree, the number of subjects was almost the same between groups. A total of $10(30.3 \%)$ NAFLD subjects had a low NAFLD Fibrosis Score, 11 (33.3\%) of NAFLD subjects had moderate Fibrosis Score NAFLD, and 12 (36.4\%) NAFLD subjects had high NAFLD Fibrosis Score (Table 1). 
Table 1. Baseline patients' characteristics

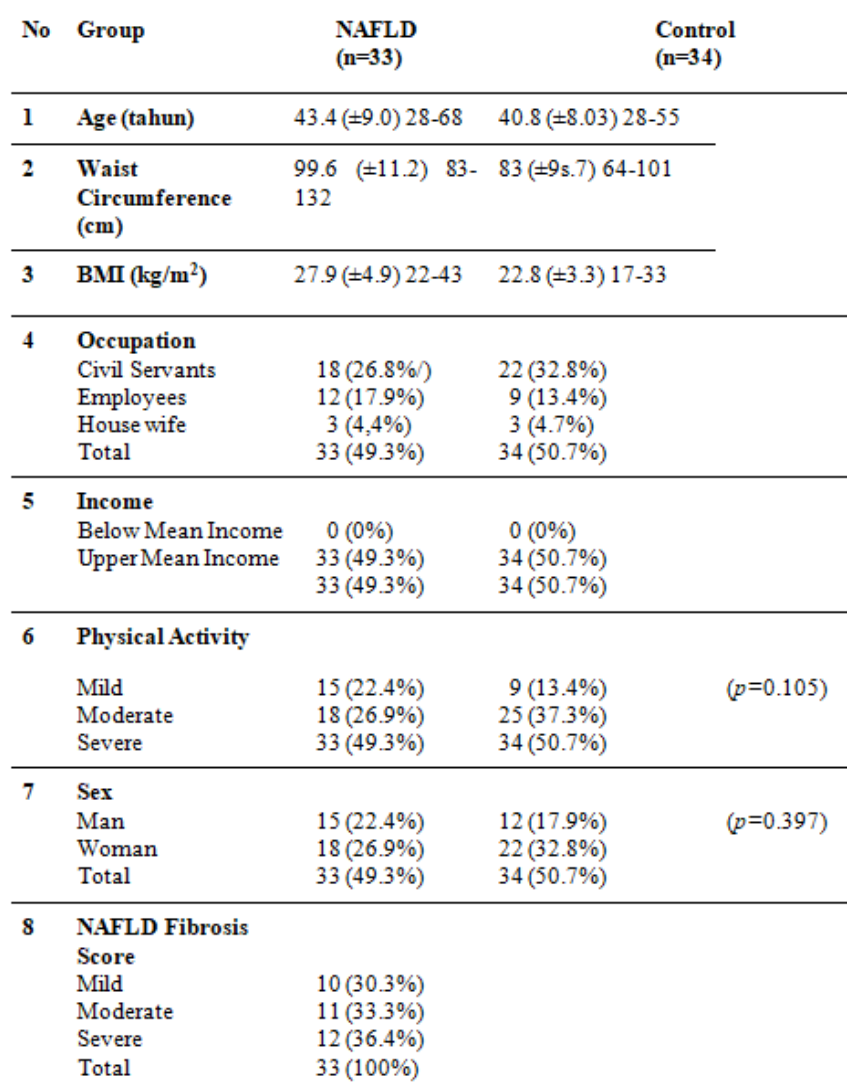

Carbohydrate and Fat intake, as well as Visceral Fat Deposition Score

Carbohydrate and fat intake in NAFLD group was higher than control. The mean visceral fat deposition based on BIA scores in the NAFLD group was higher than in the control (Table 2).

Table 2. Description of Carbohydrate, Fat intake and Visceral Fat Deposition Score of Research subject

\begin{tabular}{|c|c|c|c|}
\hline No & Variabel & $\begin{array}{c}\text { NAFLD } \\
\text { Mean } \pm \text { SB } \\
\text { (Min-Max) }\end{array}$ & $\begin{array}{c}\text { Control } \\
\text { Mean } \pm \text { SB } \\
(\text { Min-Max })\end{array}$ \\
\hline 1 & $\begin{array}{l}\text { Carbohydrate } \\
\text { In take (gram) }\end{array}$ & $\begin{array}{c}315.8 \pm 128.4 \\
(125.9-602.2)\end{array}$ & $\begin{array}{c}216.2 \pm 65.2 \\
(107.4- \\
391.7)\end{array}$ \\
\hline 2 & $\begin{array}{l}\text { Fat Intake } \\
\text { (gram) }\end{array}$ & $\begin{array}{c}74.6 \pm 36.5 \\
(17.8-204.5)\end{array}$ & $\begin{array}{c}54.8 \pm 22.7 \\
(17.9-115.4)\end{array}$ \\
\hline 3 & $\begin{array}{l}\text { Visceral Fat } \\
\text { Deposition Score }\end{array}$ & $\begin{array}{l}12.6 \pm 6.5 \\
(4.0-30.0)\end{array}$ & $\begin{array}{l}5.5 \pm 3.3 \\
(1.0-12.0)\end{array}$ \\
\hline
\end{tabular}

\section{Risk Factors of NAFLD Incidents}

In determining the risk factors for NAFLD events, the determination of the classification of carbohydrate and fat intake,

as well as visceral fat classification was based on the results of Receiver Operating Characteristic (ROC) against Recommended Daily Allowance (RDA) analys is (Figures 1)

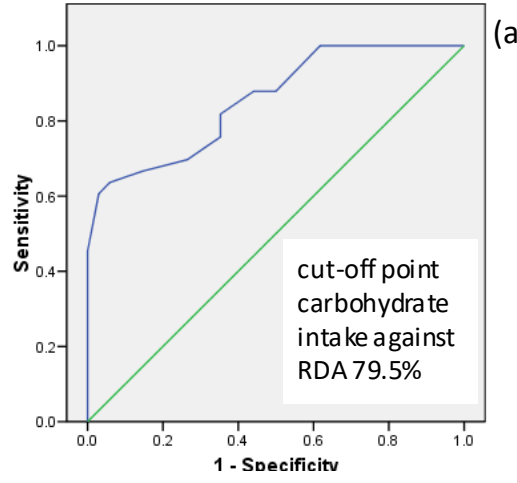

(a)

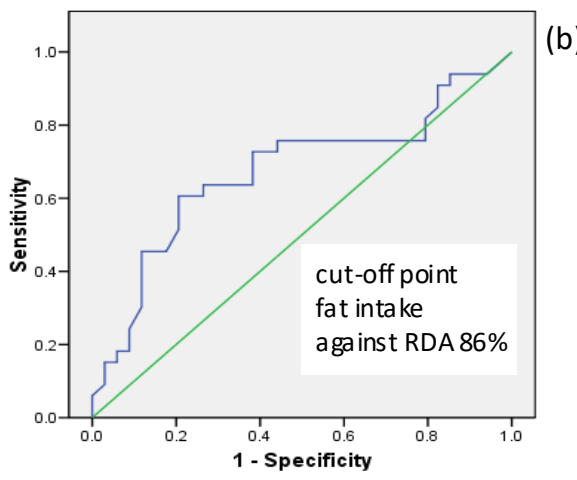

(b)

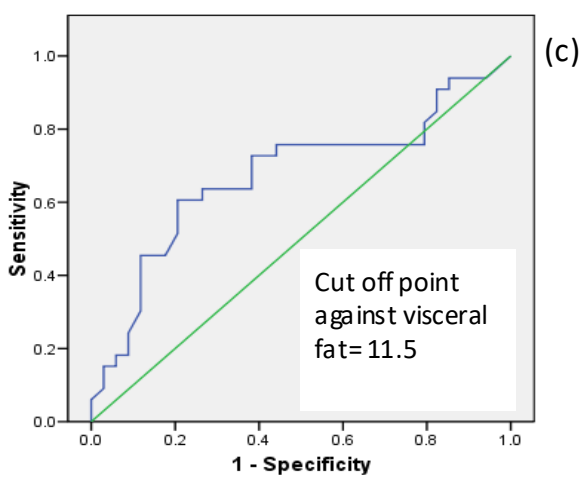

Figure 1. (a) Carbohydrate Intake against RDA. (b) Fat Intake against RDA. (c) Visceral Fat Deposition, on Case-Control Group.

In bivariate analysis towards nutritional variables such as: high carbohydrate intake, high fat intake, and high deposition of visceral fat, were shown to be the risk factor for NAFLD incidence (Table 3). Clinical markers such as visceral obesity, insulin resistance, dyslipidemia, hyper trigliseridemia, Hipo-HDL, hypertension, and metabolic syndrome were also proved to be the risk factor for NAFLD incidence.

Multivariate analysis was performed on risk factors of NAFLD incidence, indicating that hypertriglyceridemia was the most influential factor (OR 8.7, CI95\% 2.2-34.4) and visceral fat deposition (OR 5.8, CI95\% 1.39-24.8) were the independent risk factor for incidence of NAFLD (Table 3 and 4).

Table 3. Risk Factors of High Carbohydrate, High Fat Intake and Clinical Markers on NAFLD

Occurrences 


\begin{tabular}{|c|c|c|c|c|c|}
\hline No & Variabel & $\begin{array}{l}\text { NAFLD } \\
\text { N(\%) }\end{array}$ & $\begin{array}{l}\text { Control } \\
\mathrm{N}(\%)\end{array}$ & $O R(C I 95 \%)$ & $p$ \\
\hline \multirow[t]{4}{*}{1.} & Carbohydrate Intake & & & & \\
\hline & High $(>79.5 \%)$ & $19(28.4)$ & $5(7.5)$ & $7.8(2.43-25.45)$ & $<0.001$ \\
\hline & Low $(\leq 79.5 \%)$ & $14(20.9)$ & $29(43.3)$ & & \\
\hline & Total & $33(49.3)$ & $34(50.7)$ & & \\
\hline \multirow[t]{4}{*}{2.} & Fat Intake & & & & \\
\hline & High $(>86 \%)$ & $20(29.9)$ & $7(10.4)$ & $5.9(2.00-17.57)$ & 0.001 \\
\hline & Low $(\leq 86 \%)$ & $13(19.4)$ & $27(40.3)$ & & \\
\hline & Total & $33(49.3)$ & $34(50.7)$ & & \\
\hline \multirow[t]{3}{*}{3.} & $\begin{array}{l}\text { Visceral Fat } \\
\text { Deposition Score }\end{array}$ & & & & \\
\hline & High $(>11.5 \%)$ & $20(29.9)$ & $1(1.5)$ & $50.7(6.16-418.09)$ & $<0.001$ \\
\hline & $\begin{array}{l}\text { Low }(\leq 11.5 \%) \\
\text { Total }\end{array}$ & $\begin{array}{l}13(19.4) \\
33(49.3)\end{array}$ & $\begin{array}{l}33(49.3) \\
34(50.7)\end{array}$ & & \\
\hline 4. & $\begin{array}{l}\text { Central Obesity } \\
\text { Yes } \\
\text { No } \\
\text { Total }\end{array}$ & $\begin{array}{l}23(34.3) \\
10(14.9) \\
33(49.3)\end{array}$ & $\begin{array}{c}5(7.5) \\
29(43.3) \\
34(50.7)\end{array}$ & $13.3(3.99-44.51)$ & $<0.001$ \\
\hline 5. & $\begin{array}{l}\text { Insulin Resistance } \\
\text { Yes } \\
\text { No } \\
\text { Total }\end{array}$ & $\begin{array}{l}\text { ' } 12(17.9) \\
21(31.3) \\
33(49.3)\end{array}$ & $\begin{array}{c}5(7.5) \\
29(43.3) \\
34(50.7)\end{array}$ & ' $3.3(1.01-10.83)$ & 0.042 \\
\hline 6. & $\begin{array}{l}\text { Dyslipidemia } \\
\text { Yes } \\
\text { No } \\
\text { Total }\end{array}$ & $\begin{array}{l}\text { ' } 27(40.3) \\
6(9.0) \\
33(49.3)\end{array}$ & $\begin{array}{l}17(25.4) \\
17(25.5) \\
34(50.7)\end{array}$ & ' $4.5(1.48-13.66)$ & 0.006 \\
\hline 7. & $\begin{array}{l}\text { Hypertrigliseridemia } \\
\text { Yes } \\
\text { No } \\
\text { Total }\end{array}$ & $\begin{array}{c}25(37.3) \\
8(11.9) \\
33(49.3)\end{array}$ & $\begin{array}{c}5(7.5) \\
29(43.3) \\
34(50.7)\end{array}$ & $26.1(7.13-95.52)$ & $<0.001$ \\
\hline 8. & $\begin{array}{l}\text { Hipo-HDL } \\
\text { Yes } \\
\text { No } \\
\text { Total }\end{array}$ & $\begin{array}{l}17(25.4) \\
16(23.9) \\
33(49.3) \\
\end{array}$ & $\begin{array}{c}6(9.0) \\
28(41.8) \\
34(50.7)\end{array}$ & $4.9(1.62-15.12)$ & 0.004 \\
\hline 9. & $\begin{array}{l}\text { Hypertension } \\
\text { Yes } \\
\text { No } \\
\text { Total }\end{array}$ & $\begin{array}{l}15(22.4) \\
18(26.9) \\
33(49.3)\end{array}$ & $\begin{array}{c}4(6.0) \\
30(44.8) \\
34(50.7)\end{array}$ & $6.2(1.79-21.77)$ & 0.002 \\
\hline 10. & $\begin{array}{l}\text { Metabolic syndrome } \\
\text { Yes } \\
\text { No } \\
\text { Total }\end{array}$ & $\begin{array}{r}25(37.3) \\
8(11.9) \\
33(49.2)\end{array}$ & $\begin{array}{c}4(6) \\
30(44.8) \\
34(50.8)\end{array}$ & $23.4(6.30-87.06)$ & $<0.001$ \\
\hline
\end{tabular}

Table 4. Logistic Regression Test Risk Factors Against NAFLD

\begin{tabular}{lllllll} 
No & Variables & B & SE & Sig & OR & C195\% \\
\hline 1. & $\begin{array}{l}\text { Hipertrigliseri } \\
\text { demia }\end{array}$ & 2.16 & 0.70 & 0.002 & 8.7 & $2.20-34.44$ \\
\hline 2. & $\begin{array}{l}\text { Visceral Fat } \\
\text { Deposition }\end{array}$ & 1.77 & 0.73 & 0.016 & 5.8 & $1.39-24.82$ \\
& & & & &
\end{tabular}

Carbohydrates and Fats, as well as visceral fat deposition According to NAFLD Degrees

Carbohydrate and fat intake (grams), as well as visceral fat deposition (score) increase with increasing degree of NAFLD (Figure 2).
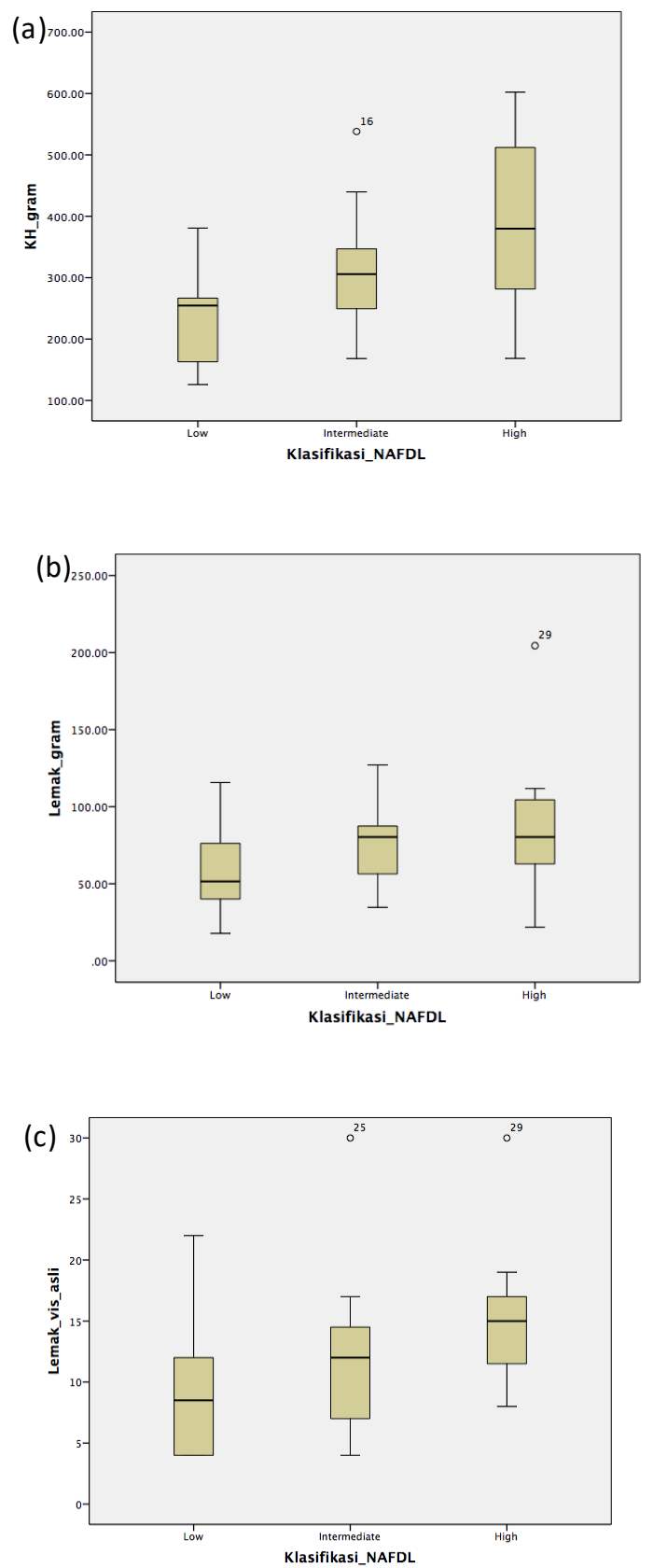

Figure 2. Corre lation Between (a) Carbohydrate, (b) Fat Intake, and (c) Visceral Fat Deposition with NAFLD Degrees

\section{Risk Factors of NAFLD Se verity}

The severity of NAFLD from the in this study is divided into 3 groups, but on the risk factor analysis for NAFLD severity we classify them into 2 groups, where the intermediate and high degree groups we make become the severity of the high degree

NAFLD. While the low degree (low) we use for comparison.

In determining the severity risk factor of NAFLD, the determination of the classification of carbohydrate and fat intake, as well as fat classification is based on the results of Receiver Operating Characteristic (ROC) analysis (Figure 3). 

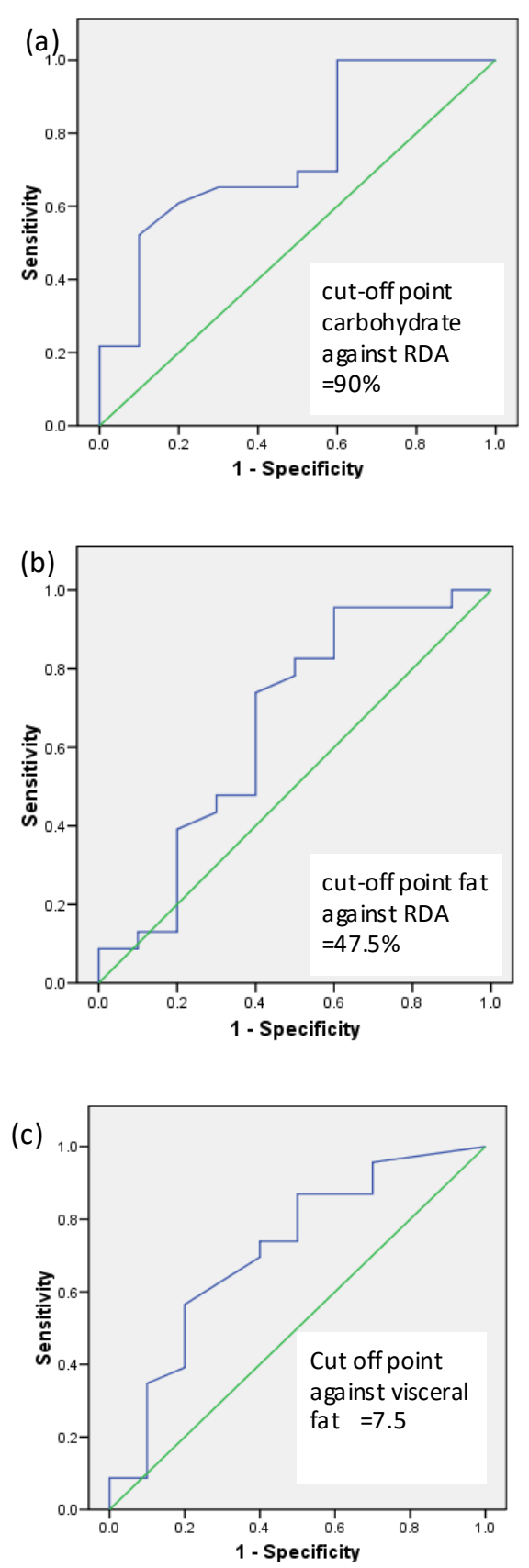

Figure 3. (a) Carbohydrate Intake against RDA. (b) Fat Intake against RDA. (c) Visceral Fat Deposition, on Case Group

Based on bivariate analysis showed high carbohydrate $(>90 \% \mathrm{RDA})$ and fat intake $(>47,5 \%$ RDA), visceral fat deposition score $>7,5 \%$ were proved as risk fators of NASH or severity of NAFLD (table 5).

However, in multivariate analysis, only high fat intake $(>47,5 \%)$ proved as a risk factor for NAFLD severity or incidence of NASH $(p=0.008)$.

Table 5. Risk Factors Carbohydrate and Fat intake, Visceral Fat Deposition Score Against the severity of NAFLD

\begin{tabular}{|c|c|c|c|c|c|}
\hline No & Variabel & $\begin{array}{l}\text { NAFLD } \\
\text { Severe degree } \\
\text { N (\%) }\end{array}$ & $\begin{array}{l}\text { NAFLD } \\
\text { Mild degree } \\
\text { N (\%) }\end{array}$ & $O R(C I 95 \%)$ & $p$ \\
\hline \multirow[t]{4}{*}{1.} & Carbohydrate intake & & & & \\
\hline & High $(>90 \%)$ & $12(36.4)$ & $1(3.0)$ & $9.8(1.06-90.58)$ & 0.023 \\
\hline & low $(\leqslant 90 \%)$ & $11(33.3)$ & $9(27.3)$ & & \\
\hline & Total & $23(69.7)$ & $10(30.3)$ & & \\
\hline \multirow[t]{4}{*}{2.} & Fat Intake & & & & \\
\hline & High (>47.5\%) & $22(66.7)$ & $6(18.2)$ & $14.6(1.37-156.88)$ & 0.009 \\
\hline & Low $(\subseteq 47.5 \%)$ & $1(3.0)$ & $4(12.1)$ & & \\
\hline & Total & $23(69.7)$ & $10(30.3)$ & & \\
\hline \multirow[t]{4}{*}{3.} & $\begin{array}{l}\text { Risk Factor of Visceral } \\
\text { Fat Deposition Score }\end{array}$ & & & & \\
\hline & $\mathrm{High}(>7.5 \%)$ & $20(60.6)$ & $5(15.2)$ & $6.6(1.17-37.78)$ & 0.023 \\
\hline & Low $(\leq 7.5 \%)$ & $3(9.1)$ & $5(15.2)$ & & \\
\hline & Total & $23(69.7)$ & $34(30.3)$ & & \\
\hline
\end{tabular}

On bivariate analysis for clinical markers on NAFLD severity showed that visceral obesity and metabolic syndrome were as risk factors for NAFLD severity consecutively (OR $7.1(1.35-37.55)$ and OR 6.6 (1.17-37.7)) (table 6).

Tabel 6. Risk Factor of Clin ical Markers on NAFLD Severity

\begin{tabular}{|c|c|c|c|c|c|}
\hline No & Variabel & $\begin{array}{l}\text { NAFLD } \\
\text { Severe degree } \\
\text { N(\%) }\end{array}$ & $\begin{array}{l}\text { NAFLD } \\
\text { Severe degree } \\
\mathbf{N}(\%)\end{array}$ & OR $(C I 95 \%)$ & $p$ \\
\hline 1. & $\begin{array}{l}\text { Central Obesity } \\
\text { Yes } \\
\text { No } \\
\text { Total }\end{array}$ & $\begin{array}{c}19(57.6) \\
4(17.4) \\
23(69.7)\end{array}$ & $\begin{array}{r}4(12.1) \\
6(18.2) \\
10(30.3)\end{array}$ & $7.1(1.35-37.55)$ & 0.014 \\
\hline 2. & $\begin{array}{l}\text { Insulin Resistance } \\
\text { Yes } \\
\text { No } \\
\text { Total }\end{array}$ & $\begin{array}{l}10(30.3) \\
13(39.4) \\
23(69.7)\end{array}$ & $\begin{array}{l}2(6.1) \\
8(24.2) \\
10(30.3)\end{array}$ & $3.0(0.53-17.7)$ & 0.198 \\
\hline 3. & $\begin{array}{l}\text { Dyslipidemia } \\
\text { Yes } \\
\text { No } \\
\text { Total }\end{array}$ & $\begin{array}{l}18(54.5) \\
5(15.1) \\
23(69.7)\end{array}$ & $\begin{array}{l}9(27.2) \\
1(3.2) \\
10(30.3\end{array}$ & $0.4(0.4-3.9)$ & 0.422 \\
\hline 4. & $\begin{array}{l}\text { Hypertrigliseridemia } \\
\text { Yes } \\
\text { No } \\
\text { Total }\end{array}$ & $\begin{array}{c}18(54.5) \\
5(15.1) \\
23(69.7)\end{array}$ & $\begin{array}{l}9(27.2) \\
1(3.2) \\
10(30.3)\end{array}$ & $0.4(0.4-3.9)$ & 0.422 \\
\hline 5. & $\begin{array}{l}\text { Hipo-HDL } \\
\text { Yes } \\
\text { No } \\
\text { Total }\end{array}$ & $\begin{array}{l}12(36.4) \\
11(33.3) \\
23(69.7)\end{array}$ & $\begin{array}{l}5(15.2) \\
5(15.2) \\
34(30.3)\end{array}$ & $1.09(0.24-4.81)$ & 0.909 \\
\hline 6. & $\begin{array}{l}\text { Hypertension } \\
\text { Yes } \\
\text { No }\end{array}$ & $\begin{array}{l}12(36.4) \\
11(33.3)\end{array}$ & $\begin{array}{l}3(9.1) \\
7(21.2)\end{array}$ & $2.5(0.52-12.36)$ & 0.240 \\
\hline
\end{tabular}

7. Metabolic Syndrome

\begin{tabular}{lcccc}
\hline Yes & $20(60.6)$ & $5(15.2)$ & $6.6(1.17-37.7)$ & 0.023 \\
No & $3(9.1)$ & $5(15.2)$ & & \\
Total & $23(69.7)$ & $34(30.3)$ & &
\end{tabular}

\section{DISCUSS ION}

The result of statistical test of the characteristics between two groups (age, sex, occupation, income, and physical activity) showed no difference, this indicated the initial condition in both groups is alike except in the variable of central obesity, insulin resistance, dyslipidemia , hypertriglyceridemia, hypoHDL, hypertension, and metabolic syndrome.

The mean of age on the NAFLD group was 43.3 years, while the control was 40.8 years. Age is one of 
the predisposing factors for NAFLD. The aging process will increase the oxidative stress that plays a role in the process of NAFLD

Insulin resistance is a risk factor for the incidence of NAFLD (OR 3.3, CI95\% 1.01-10.83). It may cause metabolic disorders of some macro nutrients due to hepatic insulin resistance resulting in increased plasma glucose concentration and increased VLDL production and cause hypertriglyceridemia. Triglycerides will accumulate in the hepatocyte so that NAFLD will occur. This result is consistent with Cortez et al's 2006 study which suggests that there is a significant difference $(p<0.01)$ between NAFLD patients in the Fatty Liver Disease with NAFLD spectrum compared with healthy control. ${ }^{48}$ Studies by Hannah et al, 2014 suggest that there was a significant difference ( $p<0.05)$ between NAFLD patients on simple steatosis spectrum and NAFLD compared with healthy control. ${ }^{49}$ This result is directly proportional to Lei et al's 2012 study, which states that RI is one of the risk factors for NAFLD with 4.96 times compared with healthy control (95\% CI 1.10-22.266). ${ }^{50}$

Each of the metabolic syndrome components such as central obesity, dyslipidemia, hipertrig liseridemia, hipo-HDL, insulin resistance and hypertension as well as stand-alone variables as the variables studied are risk factors for NAFLD events. Metabolic syndrome is the risk factor for the incidence (OR 23.4, CI95\% 6.30-87.06) and severity of NAFLD (OR 6.6, CI95\% 1.17-37.7), as well as central obesity (CI95\% 1.35-37.55).

Multivariate analysis showed that hypertriglyceridemia and fat intake were independent risk factor for NAFLD incidence. These results fit the theoretical basis that dyslipidemia, in particular hypertriglyceridemia, can result from a high fat intake and may increase the risk of incidence and severity of NAFLD. ${ }^{31,32}$ The results of this study are consistent with Lei et al's 2012 study of multivariate tests suggesting that dyslipidemia increased the risk of incidence of NAFLD 4.405 times compared with healthy control $(\mathrm{p}=0.004) .^{50}$ Similarly, Hannah et al's study, 2014, stated that there was a significant difference in the presence of dyslipidemia $(p=0.05)$ between NAFLD patients with healthy control. ${ }^{49}$ There was a 4-11 times individual risk with metabolic syndrome to suffer NAFLD than healthy individuals. ${ }^{33}$

Descriptive analysis (box plot) showed that average carbohydrate intake in NAFLD group was higher than control. Average fat intake in NAFLD group was also higher than control. The results were consistent with Cortez's 2012 study suggesting that fat and carbohydrate intake in NAFLD patients was higher than in controls and significantly different. ${ }^{48}$ The Israeli study by Sagi et al, 2007 showed different results, whereas fat intake in NAFLD and healthy control, showed no difference $(\mathrm{p}=0.76)$ similar with carbohydrate intake also no difference $(p=0.6)$. Although the intake of both groups was not significantly different, the multivariate analysis showed that carbohydrate intake (from soft drinks) was a risk factor for NAFLD (OR 1.45, CI95\% 1.131.85) . After classification based on ROC curve cutoff, intake of carbohydrate and fat to RDA according to individuals, showed a relationship of fat and carbohydrate intake with the incidence and severity of NAFLD. Intervariable test showed that high carbohydrate and fat intake increased risk of NAFLD incidence $(\mathrm{OR}=7.8,95 \% \mathrm{CI} 2.43-25.45),(\mathrm{OR}=5.9$, CI95\% 2.00-17.57). High carbohydrate and fat intakes increase the risk of NAFLD severity (OR = $9.8,95 \%$ CI 1.06-90.58), $(\mathrm{OR}=14.6$, CI95\% 1.37 156.88).

Increased intake of carbohydrate and fat is closely related to elevated blood glucose, FFA, insulin concentration. A person with a higher fat intake (>37\%), would increase the risk of NAFLD by 2.51 times compared with healthy control. ${ }^{51}$ High fat intake along with IR through LpL and the genetic changes of the fat metabolism pathway will increase the blood FFA so that the concentration of TG and $\mathrm{CE}$ in the liver and fat in the muscle increases and accumulates. Excessive carbohydrate intake combined with IR will also increase the stimulation of de novo lipogenesis so that glucose in the liver increases. Glucose will be converted to glycogen and FFA. Glycogen will increase FC and increase CE, whereas FFA will increase TG and CE and eventually lead to excessive accumulation of TG in the liver and infiltrate hepatocytes and then form NAFLD. ${ }^{12}$ FFA also increase DAG (d iacylglyserol). Accumu lation of DAG interferes with insulin signaling in the liver by activation of protein kinase-C. Ceramide on the spingolipid membrane will also increase FFA in the liver and contribute to insulin resistance through activation of proinflammatory cytokines, cell apoptosis and increased endoplasmic reticulum stress. ${ }^{52}$

High visceral fat deposition is a risk factor for the incidence and severity of NAFLD (OR 50.7, 95\% CI 6.16-418.09), (OR 6.6, 95\% CI 1.17-37.78). The visceral fat deposition in a person with obesity and overweight will increase adipose tissue, where adipose tissue is the site of macrophage accumulation which is the main source of TNF- $\alpha$ expression. TNF$\alpha$ secretion then stimulates MCP- 1 by preadipocytes. TNF- $\alpha$, interleukin- 6 , interleukin $-1 \beta$ are secreted by activated macrophages. ${ }^{12}$ These proinflammatory cytokines will lead to stem cell activation and cause fibrosis, in addition the kupfer cells will also be activated to produce proteins acute phase such as CRP and protrombosis molecules all of which will result in liver tissue damage (Hit 2) ${ }^{.12}$ Increased visceral fat deposition boosting proinflammatory cytokines will also increase ROS, affect lipid peroxidation and decrease adiponectin. Adiponectin is an anti-inflammatory adipocytokine that modulates the effects of insulin. Adiponectin levels are negatively correlated with fasting sugar levels, and insulin resistance and TG levels. Decreased adiponectin will promote more intensive necroinflammation in NAFLD. High necroinflammation will increase ROS and lead to increased peroxidation of further pro-inflammatory lipid and 
cytokine products leading to cell death, inflammation, and fibrosis. ${ }^{53}$

The result of multivariate test stated that hypertriglyceridemia was the independent risk factor for the incidence of NAFLD. Hypertriglyceride is the beginning of triglyceride buildup in the liver which will damage the structure and function of the liver so that it develops into various diseases like IR, DM, dyslipidemia, and metabolic syndrome which is a pathogenesis that can not be separated with NAFLD disease. Nevertheless, the above risk factors after the regression test contributed $55.3 \%$, and as much as $44.7 \%$ may be influenced by other factors not investigated but related to NAFLD.

The overall risk factors above must be addressed comprehensively. Handling either medically or nonmedically as nutrition therapy as indicated or with lifestyle changes, and good dietary regulation, and education to the patient as a follow-up to prevent NAFLD should be done.

The limitations of this study are: data was taken from a single measurement, so that can not always describe a relationship in the longer time. FFQ method, has weakness, including recall bias, and underestimate or even overestimate the size of household food subject intake. FFQ can not provide information about the intake of simple carbohydrates, fructose, or certain antioxidant intake that may be related to the process of NAFLD.

\section{CONCLUS ION}

High carbohydrate intake, fat intake, and high visceral fat deposition are risk factors of the incidence and severity of NAFLD. Hypertriglyceride mia and fat intake are the most important risk factor of NAFLD incidence and severity, respectively.

\section{ACKNOWLEDGMENTS}

We would like to thanks to Putri Dwi Astuti (Departement of Internal Medicine Medical Faculty Diponegoro University Semarang) for contribution in preparing and editing this manuscript for publication.

\section{REFERENCES}

1. Marcos E. Non alcoholic fatty liver disease. Pediatric Annals. 2006; 35(4): p.291-99.

2. Medina J. Approach to the Pathogenesis and Treatment of Nonalcoholic Steatohepatitis. Diabetes Care. 2004; 27 :p.2057-66

3. Bowman J. Systematic Review: the diagnosis and staging of non alcoholic fatty liver disease. Aliment Pharmacol Ther. 2011;33: p.525-40.

4. World Gastroenterology Organisation. Nonalcoholic Fatty Liver Disease and Non Alcoholic Steatohepatitis. World Gastroenterology Organisation Global Gu idelines. 2012: p.1-29.

5. Mc Cullough. The Epidemiology and Risk Factor of NASH. In Fatty liver Disease NASH and Related Disorder, Geoffrey C Farrel, eds. Oxford: Blackwell Publishing Ltd.2005: p.2337.

6. Day CP. NASH: Where are we now and where are we going? Gut. 2002; 50: p.585-88.

7. Sagi S, Goldsmith R, Webb M. Long Term Nutritional Intake and The Risk for Nonalcoholic Fatty Liver Disease : A Population Based study. Journal of Hepatology. 2007;47: p.711-17.

8. Perseghin G. Lipids in The Wrong Place: Visceral Fat and Nonalcoholic Steatohepatitis. Diabetes Care. 2011; 34(2).

9. Almatsier S. Prinsip Dasar Ilmu Gizi. Jakarta: PT. Gramedia Pustaka Utama. 2001. p. 28-47.

10. Dedeh K, Marfuah P, Saeful I. Sehat dan Bugar Berkat Gizi Seimbang. Jakarta: Kompas Gramedia. 2010.p.101-24.

11. Smith A, wardlaw G. Contemporary Nutrition. United States of America: Mc Graw Hill Companies. 2009.p.120-234.

12. Zivkovic A, Sanyal A. Comparative riview of diets for the metabolic syndrome: implications for nonalcoholic fatty liver disease. American Journal of Clinical Nutrition. 2007; 3: p.285-96.

13. Muchtadi D, Astawan M, Palupi N. Metabolisme Zat Gizi : Sumber, Fungsi, dan kebutuhan bagi Tubuh Manusia. Jakarta: Pustaka Sinar Harapan; 2000.

14. Gibson R. Principles of Nutritional Assessment. New York: university of Michigan Press. 2005 : p.127-227.

15. Siagian A. Epidemiologi Gizi. Jakarta: Penetbit Erlangga. 2010 : p.11-33.

16. Nyoman D, Bakri B, Fajar I. Penilaian Status Gizi. Jakarta: EGC. 2001: p.21-39.

17. Masuzaki H. A Transgenic Model of Visceral Obesity and the Metabolic Syndrome. Science. 2001; 294: p.2166-70.

18. Mathieu P, Poireier P, Pibarot P, Lemieux I. Obesitas Visceral: Hubungan Antara Inflamasi, Hipertensi, dan Penyakit Cardiovaskuler. American Heart Association. 2009; 53(577).

19. Kyle A, Ursula G, I Bosaeus, al RLe. "Bioelectrical impedance analysis-part I: review of principles and methods". J of Clinical Nutrition. 2004; 23(5): p.1226-43.

20. Bohm A, Heitmann B. The use of bioelectrical impedance analysis for body composition in 
epidemiological studies. European Journal of Clinical Nutrition. 2013: p.67-79.

21. Westphal B, Later A, Hitze W, Sato B, Kossel T. Accuracy of Bioelectrical Impedance Consumer Devices for Measurement of Body Composition in Comparison to Whole Body Magnetic Resonance Imaging and Dual X-Ray Absorptiometry. Obesity Facts. 2008; 1(6):6.

22. Chasalani N. The Diagnosis and Management of NAFLD : Practice Guideline by the American Association for the Study of Liver Disease, American College of Gastroenterology, and the American Gastroenterological Association Official Journal of the American Association for the Study of Liver Disease. 2005: p. 209-28.

23. Sasdesi L, Purnomo HD. Data Kunjungan Pemeriksaan Ultrasonografi Abdomen Instalasi Radiologi RSUP Dr Kariadi Semarang . 2010.

24. Hasan I, Machmud R. Prevalence and risk factors for nonalcoholic fatty liver in Indonesia. J Gastroenterol Hepatol. 2002; 17(154) : p.6781.

25. Amarapurkar D. NAFLD current concepts. International Journal of Hepatology. 2012: p.4549.

26. Zimmet P, Matsuzawa Y. The Metabolic Syndrome: A Global Health Problem and A New Definition. J Atheroscl Thromb 2005; 12: p.295-300.

27. Amarapunkar D. Prevalence of non-alcoholic fatty liver disease: population based study. Annals of Hepatology. 2007; 63: p.161-63.

28. Purnomo HD. Peranan Sindrom Metabolik dan Beberapa Biomarker pada Kejadian dan Keparahan Penyakit Perlemakan Hati Bukan Karena Alkohol. Semarang: Universitas Diponegoro. 2013. p.1-156.

29. Weston S, Murphy R. Racial and ethnic distribution of nonalcoholic fatty liver in person with newly diagnosed liver disease. Nutrition in clin ical care. 2005; 41: p.372-79.

30. Williams C. Prevalence of Nonalcoholic Fatty Liver Disease and Nonalcoholic Steatohepatitis Among a Largely Middle Aged population Utilizing Ultrasound and Liver Biopsy : A prospective Study. Gastroenterology. 2011; 140(1) : p.124-31.

31. Marchesini G, Forlani G. Non alcoholic fatty liver, steatohepatitis, and the metabolic syndrome. Hepatology. 2003; 37(4) : p.917-23.
32. Eric Y, Fransisco D, Myron T. Nonalcoholic Fatty Liver Disease: Pathogenesis, Identification, Progression, and Management. Nutrition in clinical care. 2007;1: p.376-84.

33.Bellentani S, Masutti F. Prevalence of and risk factor for hepatic steatosis Ann Intern Med. 2000;132: p.112-17.

34. Hasan I, Setyohadi B, Alwi I, Simadibrata M, Setiati S. Perlemakan Hati Non Alkoholik. Buku Ajar Ilmu Penyakit Dalam Jakarta: Pusat Penerbit Ilmu Penyakit Dalam FK UI; 2006. p. 464-72.

35. Sakugawa H. Clinical Usefullness of Biochemical Markers of Liver fibrosis in Patient with Nonalcoholic Fatty Liver Disease. World Journal Gastroenterology. 2005;11: p.255-9.

36. Loke K. Consenquences of childhood and adolescent obesity. Journal of Clinical Nutrition 2002;11. p.702-09.

37. Adams L, Lindor K. Nonalcoholic fatty liver disease. CMAJ. 2005; 7: p.899-905.

38. Sporea I, Basa E, Corianu M, Popescu A. The value of transabdominal ultrasound for assessment of the severity of liver steatosis as compared to liver biopsy. Cent Eur J Med. 2009; 4(4) : p.490-95.

39. Bisset R. Liver, biliary system, pancreas and spleen. In: Differential Diagnosis In Abdominal Ultrasound. 2 ed. London. 2001. P.203-78

40. Angulo P. Nonalcoholic fatty liver disease. $\mathrm{N}$ England J Med. 2002; 346 : p.1221-31.

41. Sherlock S. Disease of the liver and biliary system. Willey-Blackwell. 2011.p.71-81.

42. Despres J, Lemieux I. Abdominal Obesity and Metabolic Syndrome. Eur J Endocrinol Invest. 2006 (444): p.881-87.

43. Thamer C, Machann J, Stefan N, Haap M, Schifer S. High Visceral Fat Mass and High Liver Fat are Associated with Resistance to Lifestyle Intervention. J Obesity. 2007; 15(2): p.531-38.

44. Nakajima T, Nakashima T, Yamaoka J, Shibuya A, Itoh Y, Yoshikawa T. Age is a Negative, and Visceral fat Accumulation is a Positive, Contributor to Hepatic Steatosis, Regardless of the Fibrosis Progression in Non-alcoholic Fatty Liver Disease. Journal of Gastroenterology and Hepatology Research. 2012;1(11): p.315-19. 
45. Jensen D. Is Visceral Fat Involved in the Pathogenesis of the Metabolic Syndrome? J Obesity. 2006;14(1): p.20-24.

46. Naniwadekar A. Nutritional Recomendation for Patien with NAFLD: An Evidence Based Riview. Nutritional Issues in Gastroenterology. 2010; 82 : p.8-16.

47. Sastroasmoro S, Ismael S. Dasar-dasar Penelitian Klinis: Edisi 4. Jakarta: CV.Sagung Seto. 2011 :p.27-108.

48. Cortez P, Baros H, Lopes C, et al. How Different is the Dietary Pattern in NonAlkoholic steatohepatitis Patients? An International Journal Devoted to Clinical Nutrition and Metabolism. 2006: p.816-23.

49. Hannah E, Bianca A, Seham A, George T, Maha G. A cross sectional study assessing dietary intake and physical activity in Canadian patient with nonalcoholic fatty liver disease vs healthy controls. Journal of The Academy of Nutrition and Dietetics. 2014;114(8): p.1181-94.

50. Lei S, Zhong L, Cai G, Li S, Cheng H, Ming L. The prevalence of nonalcoholic fatty liver disease and its association with lifestyle/dietary habits among university faculty and staff in Chengdu. Biomed Environ Sci. 2012;25(4): p.383-91.

51. Erin M, Mary R. The role of diet and nutrient composition in nonalcoholic fatty liver disease. Journal of The Academy of Nutrition and Dietetics. 2012;112(3): p.401-9.

52. Koppe S. Obesity and the liver: nonalcoholic fatty liver disease. Translational Research. 2014;164(4): p.312-18.

53. Yoon D. Hypoadiponectinemia and insulin Resistance are associated with Nonalcoholic Fatty Liver Disease. Journal Korean Medicine. 2005. p. 20-29 